\title{
4. Splicing the perspectives of the Commonwealth and states into a workable federation ${ }^{1}$
}

\section{Terry Moran AO}

In my view, we are on the verge of a revived federalism, which holds great possibilities for Australia in the twenty-first century. By this I do not mean we are about to eliminate or radically diminish the power of the states or any other critical element of the institutions of the federal system. Rather, we are on the threshold of entering into a new compact between governments, which contains the potential to confer several benefits on the Australian people:

- improved levels of service from government, based on a strategic agreement on what the focus should be

- better outcomes across a wide front

- increased productivity that will lift our living standards still further

- important new strategic initiatives.

Having been in public administration at the Commonwealth and state level, I can say that talent and creativity are to be found at both levels of government. We can harness these strengths to deliver enhanced economic and social outcomes for Australia.

So I don't intend to propose a radical solution, of either diminishing or substantially enlarging the powers of one or another constitutional actor.

Of course, the lawyers among you might first think of constitutional reform as the key to transforming Commonwealth-state relations for the better. That is certainly a conversation worth having.

As the Special Minister of State remarked in his speech for Constitution Day celebrations in July 2008, there was a strong case for updating what he described as the 'stump-jump plough' of constitutions.

However, I can only agree with Senator Faulkner's judgment that Australians on the whole are a sceptical lot who must be thoroughly convinced that any proposed changes will deliver practical and necessary improvements on the current system.

Where constitutional reform is concerned, that has always been a tough job. A number of ideas were put forward at the 2020 Summit for potential constitutional reform. The government is currently considering these proposals. 
However, for those of us who deal in public policy, it is clear we have made enormous progress even without any fundamental change in the institutions to which the constitution gives rise.

We as Australians demand a great deal of ourselves and our governments. This has led to the continuous pursuit of practical but necessary improvements within the parameters of the current arrangements. And when challenges have arisen, we have worked constructively to find a way through.

The cooperative forces that forged the federation compact in the first place have continued to ensure that our country works. As greater fiscal power has moved to the Commonwealth, community attitudes have also changed.

Now there is broader acceptance of the Commonwealth taking an interest in a larger array of domestic government activity. But this is not to say the community wants outright Commonwealth control.

We have all come a considerable distance-but this is not to diminish the challenge still before us.

So in considering the future of Australian federalism, I would like first to discuss some recent research, the core challenges for the future and then turn to the ambitious program of reform that COAG currently has before it.

\section{Griffith University's federalism project}

One of the most striking findings to emerge from Griffith University's Federalism Project was that over two-thirds of Australians thought the current federal system was working quite well or even very well.

This might seem surprising, given the crowd's well-publicised reaction at the 2020 Summit when former Deputy Prime Minister Tim Fischer declared that his regional and rural stream had 'almost abolished the states'.

Almost 80 per cent of respondents agreed that the Commonwealth should intervene in cases where state governments had not resolved important issues.

And yet, over half of those surveyed also agreed with the principle of subsidiarity, that decision-making power should be devolved to the lowest competent level of government.

Clearly, the ways people view their relationships with governments are diverse and complex.

While some Australians did support wholesale abolition of one or more levels of government, almost one-third supported the addition of a new regional level. Almost 60 per cent, given the choice, said they would prefer to have three or more levels of government. 
When asked to consider all current levels of government, 50 per cent of Australians rated the Commonwealth Government as the most effective at 'doing its job'.

In contrast, only 18.1 per cent rate the state level as the most effective, and 19.9 per cent rate the local level of government as the most effective.

Of course, views depended to some extent on the state the respondents called home. As a Victorian, I couldn't comment on the fact that almost two in five New South Welshmen said they would be happy to do away with state government altogether.

But it was heartening to learn that only one in four Victorians shared this view.

\section{Twomey and Withers' federalist paper for the Council for the Australian Federation}

There are undoubted benefits from federation. Professors Anne Twomey and Glenn Withers — whom you've heard from earlier at this conference - summarised the economic and social benefits of federalism in their first federalist paper.

They find that federalism:

- divides and limits power between different players in the system and protects the individual

- gives Australians a wider range of choices and allows policies and services to be tailored to meet the needs of communities

- spurs Australian governments, at all levels, to be more innovative and responsive to the needs of the community.

\section{Victorian Skills Reform package}

One example of this innovation is the Victorian Skills Reform package announced by the Brumby Government in August 2008. It is a perfect example of how state governments, with the assistance of the Commonwealth, can create and implement groundbreaking and far-reaching reforms, which will have a positive impact on the economy and future generations.

The centrepiece of the package is a redesigned investment model, which pursues two important reform agendas: a training guarantee and increasing market mechanisms.

The introduction of a training guarantee in post-compulsory education is a world first. In introducing this guarantee, the governments have committed to uncapped public funding for all Victorians in need of training, and it demonstrates an unparalleled commitment to developing a skilled workforce. 
The package is one of the most significant microeconomic reforms introduced by a state government within the past 20 years. It creates structural change in the training market by:

- placing the purchasing power in the hands of the clients

- increasing contestability and introducing price competition

- aligning government funding to public benefit.

With the support of the Commonwealth Government, all students studying a diploma or advanced diploma will be able to access an income-contingent loan in the form of FEE-HELP.

This initiative will mean additional hundreds of thousands of Victorians accessing training related to employment in the next few years.

In Withers' technical analysis, he found that, depending on which statistical approach one took:

- for the past half-century, federations had a 15.1 per cent advantage in average income growth

- the average advantage of federations in their practise of fiscal decentralisation was 8 per cent

- the average federation benefit was 10.46 per cent.

On any of these figures, there is a distinct economic advantage to a federal system. As compared with centralised unitary governments, federal nations such as Australia tend to have more efficient governments, higher rates of economic growth and higher income growth.

The reasons why we want and need to make federalism work better and enable it to reach its full potential are summed up in the six 'Cs' as presented by Twomey and Withers:

- a meaningful and effective federation is also a Check on power

- an effective federation offers Choice and diversity

- a federation provides Customisation of policies according to the different needs of states and territories.

At the same time, a federation instils healthy Competition, Creativity and, most of all, Cooperation.

Many of these elements underpin the approach to a reinvigorated COAG.

These perceived benefits have also guided significant devolution in France, Germany, Italy, Spain, Switzerland and the United Kingdom over the past decade.

However, when federalism is discussed, it is often about the inefficiencies of federal systems. Instead, we need to focus upon improving it to get the most out of it, socially and economically. 
It is not impossible. In an increasingly competitive globalised world, we also need to undertake these reforms to position Australia competitively for the future.

So we currently face a paradox: the federation provides considerable benefits but it is also seen as the 'horse and buggy' of government arrangements.

It is easy to speculate on the reasons for this:

- there has been a deal of duplication and excessive levels of administrative burden at the state and the national level of government

- this directly or indirectly can result in a lack of coordination of services for the consumer and the community

- the blurring of lines of responsibility over time for clients can lead to frustration and inefficiency-and the related blurring of political accountability.

Taken together, these views might have contributed to a belief that the federation is an accident of history irrelevant to contemporary circumstances.

This is not a view to which I subscribe, but as I have already said, it does not mean that I do not see significant scope to improve the situation.

The Commonwealth Government has now been in office for a little over nine months.

In the Prime Minister's address to the National Press Club of 27 August, he outlined the government's long-term agenda for reform. Some of the particulars might have been overlooked in all the commentary surrounding his vision for an education revolution, but in essence, he set out the five key priorities for the government:

- building a more secure Australia, given the national security challenges we faced

- building a stronger Australia, with a successful economy to enable us to deliver on the needs of our people

- building a fairer Australia, based on equality of opportunity, a humane safety net and acting on disadvantage

- an Australia capable of meeting the significant new challenges of the twenty-first century, including climate change

- a new way of governing.

It is clear that in so many ways, the work of COAG is contributing directly to progressing these key themes.

In relation to the new way of governing, for example, COAG has a significant role to play, in improving the mechanisms for intergovernmental cooperation, clarifying roles and responsibilities and establishing a new financial framework. 
It is not always possible, however, to reallocate functions on a 'clean lines' approach.

Sometimes power will need to be shared and, in such cases, needs will be reassessed in the best interests of good outcomes for the community, in redefining roles and managing these shared responsibilities.

\section{Key challenges for the future}

I turn now to the task of building a stronger economy and a fairer Australia, capable of addressing the challenges of the twenty-first century.

Whether it is climate change, an ageing population, long-term skill shortages, infrastructure bottlenecks or productivity growth, Australia continues to face major long-term challenges.

The Commonwealth can't tackle all these challenges on its own, nor does it want to. These challenges demand approaches that rise above traditional divides in the federation.

According to Michael Keating and Glyn Davis in their book The Future of Governance, ${ }^{2}$ Australia's current economic success is, in part, the product of Commonwealth-state cooperation on competition policy in the 1990s.

Indeed, the Productivity Commission (April 2005) estimated that the National Competition Policy (NCP) and related reforms in the 1990s directly increased Australia's GDP by 2.5 per cent, or $\$ 20$ billion.

I think the current COAG process has now reached a point where it is apparent that the total body of reform possibilities is broader and more substantial than all of the national competition policy reforms of the 1990s.

We need a bold approach to reform. And to achieve such reform, we need a new way of governing - in particular, increased cooperation between federal, state and local governments, businesses and community organisations.

A renewed belief in the possibility of reform was apparent at the 3 July 2008 COAG meeting. Leaders reaffirmed their commitment to the goals of the COAG reform agenda to address the challenges of:

- boosting productivity

- increasing workforce participation and mobility

- delivering better services for the community.

Reforms in these areas will in turn contribute to achieving broader goals of social inclusion, closing the gap on Indigenous disadvantage and environmental sustainability.

An overriding principle is that the key to building a strong economy is long-term productivity growth and participation in the workforce. 
As the Prime Minister has said, the Commonwealth is committed to building long-term prosperity by investing in five key platforms for productivity growth:

- an education revolution-improving the qualitative and quantitative investment in the skills of the workforce

- an infrastructure reform program-kicked off by the government's establishment of the $\$ 20$ billion Building Australia Fund

- investing in innovation and the industries of the future

- creating a seamless national economy through business deregulation

- finally, taxation reform.

The long boom has convinced many that prosperity is solving most problems. In truth, we cannot take prosperity for granted and the COAG reform agenda I have outlined above will be crucial for delivering long-term productivity growth to underpin a strong economy.

Creating a fairer Australia is also a key priority for the government. Disadvantage holds the economy back by reducing workforce participation.

The government's challenge is to bring these Australians back into the mainstream through a reform agenda of social inclusion.

The Commonwealth Government will be pursuing new ways of doing this including through COAG.

In March 2007, the Productivity Commission reported that the full implementation of reforms in human capital, competition and regulation would, over 25 years, grow the economy by 12 per cent (more than $\$ 100$ billion a year) and bring great economic and social benefits to individuals, families, communities and businesses.

This is a substantial body of work and a tribute to the willingness of the state and territory governments to end the blame game in the interest of Australia and Australians.

\section{COAG - a new reform framework}

In December 2007, we all returned to the COAG table with renewed vigour and a comprehensive reform agenda for Australia. Four COAG meetings have been scheduled for 2008 to deliver a substantial body of work on the agenda.

Central to this is sweeping reform to the architecture of Commonwealth-state funding arrangements. Key elements of a new intergovernmental agreement on Commonwealth-state financial arrangements will be finalised by the end of 2008, following extensive work by treasurers and the COAG working groups.

The intention of this reform is that states will be able to deploy Commonwealth Specific Purpose Payments (SPPs) more effectively and creatively, with enhanced 
public accountability. New National Partnership (NP) agreements will sharpen the incentives for reform.

Specific Purpose Payment base funding has tended to be viewed in terms of funding shares provided by each level of government.

The new agreements for SPPs will replace input controls with a rigorous focus on the achievement of objectives, outcomes and outputs. That is, the agreements will focus on what services the states and territories can deliver, without prescribing how this is to be achieved.

The COAG working groups have been developing outputs, outcomes and performance measures for the new agreements in areas such as health, schools, vocational education and training, affordable housing and disabilities.

These new arrangements should lead to the greater choice, competition, creativity and customisation that I referred to earlier - and ultimately to delivery by the states and territories of better outcomes for people.

The new financial framework will result in fewer SPPs - many of the existing payments will be combined into a smaller number of new payments - but no reduction in total Commonwealth funding.

These reforms will better clarify roles and responsibilities, reduce duplication and provide greater flexibility for states and territories to put money into areas where they can produce the best outcomes for their communities.

The revised SPPs will be augmented by new NPs. These partnership arrangements will:

- $\quad$ provide funding for specific projects in areas of joint responsibility, such as in interstate transport

- provide payments to facilitate reforms to lift standards of service delivery

- reward states that deliver on nationally significant reforms.

This new Commonwealth-state financial arrangement will provide the platform for improving economic, social and environmental outcomes.

This architecture will also be crucial to improving performance in service delivery in the states. States and territories will have more flexibility to pursue different forms of service delivery that best suit their circumstances.

But the flip side is that in return for increased Commonwealth funding under NPs, the Commonwealth will expect improved delivery of services, key measurable outcomes and outputs.

The states and territories are important partners in this process. The Commonwealth Government's challenge to them is to commit to concrete, tangible reforms. 
And our commitment is to match ambitious policy reform delivering better outcomes for people with new financial support. This bargain forms part of the government's upcoming negotiations for reform in the key areas of health, education and Indigenous affairs.

This is a significant development in managing Commonwealth-state relations and a step forward in improving government services to people. Let me talk about some of these in more detail.

\section{Health}

COAG has agreed that the new National Healthcare Agreement would be signed in December 2008 with new funding arrangements to commence on 1 July 2009.

This new agreement will go beyond previous agreements - and the current hospital system - to encompass primary health care, prevention and the acute and aged-care systems. And it will spell out the agreed accountability framework of all governments (Commonwealth, state and territory) for the objectives, outcomes and outputs in these areas.

Key priorities include reform and additional service provision in hospitals, preventative health, closing the Indigenous health gap and fixing the intersection of aged care, disability services and mental health roles and responsibilities.

The Commonwealth Government is willing to provide extra funding for health - but expects in return real reform in the sector and for more funding to result in the provision of more services.

\section{Schools}

In relation to schools, as the Prime Minister announced on 27 August, the three central pillars of reform that the Commonwealth aims to achieve through COAG this year are:

- improving the quality of teaching

- making school reporting properly transparent

- lifting achievement in disadvantaged school communities, including closing the gap between Indigenous and non-Indigenous students in terms of literacy and numeracy achievement, as well as year 12 (or equivalent) attainments.

A major thrust of the schooling reform agenda is to embed quality teaching. Raising teacher quality provides the platform for lifting student engagement and performance, as well as making progress on other school reforms.

A particular challenge for most education systems (including Australia's) is to attract quality teachers in 'hard-to-staff' schools.

In recent years, the United States and United Kingdom have implemented innovative and successful programs - the Teach for America and the Teach First 
programs - where highly talented graduates are given an accelerated pathway into teaching in difficult and challenging schools for two years.

These programs have given talented young graduates a taste of teaching - and many have made it their profession as a result.

One aim of the Commonwealth's new partnership with the states and territories, beginning in 2009, is to establish a similar scheme in Australia.

These are just some features of two streams of COAG work.

\section{Better ways to deliver}

The new financial framework and reforms being pursued through COAG are the result of creative experimentation and innovation.

We intend to keep monitoring how this innovation is working. The COAG Reform Council will be able to make an independent assessment of whether predetermined milestones and performance benchmarks have been met and it will also highlight examples of good practice and performance around the country.

In effect, it will provide continuous feedback on the success of the new financial arrangements in driving reform that leads to better outcomes for Australians in such important areas as health, education and closing the gap on Indigenous disadvantage.

\section{Conclusion and looking forward to 2009 and beyond}

The COAG meetings during the remainder of 2008 will focus on finalising policy reforms and the new financial arrangements, which will in turn reform Commonwealth-state relations; I am confident this will be for the better.

As well as a full policy agenda, addressing these key challenges will be a major focus of endeavour for COAG officials for 2009.

The new National Healthcare Agreement will set the groundwork for the first stage of health system reform.

The final report of the National Health and Hospitals Reform Commission in June 2009 will provide recommendations for a second round of reforms to address the interface between the public and private health sectors, the health workforce and integration of care across the health system.

We also need to reform service delivery with a 'citizen-centred' focus that can be more responsive to community needs.

As the Prime Minister said early in 2008, we must 'continue to reform the system of government and government service so that citizens lie at the centre, rather than the inflexible behemoths of official bureaucracy'. 
I agree with the Prime Minister that government is not the repository of all wisdom, that there are limits to what governments can effectively do and that the private and community sectors have much to offer.

We look forward to working with groups across the community to improve the delivery of government services.

I believe the Commonwealth and state and territory governments have a great opportunity to reach agreement.

And I am also confident, given the evidence of goodwill that I have seen from states and territories and the Australian Local Government Association (ALGA), that we can achieve far-reaching reform.

From the Commonwealth's point of view, it marks just the beginning - the beginning of a period of long-term reform to tackle the nation's long-term challenges; we have to achieve this in order to ensure better outcomes for the people of Australia.

\section{ENDNOTES}

1 This essay was originally presented as a keynote address at the ANZSOG Annual Conference on 12 September 2008.

2 Keating, Michael and Davis, Glyn 2000, The Future of Governance, Allen \& Unwin, Melbourne. 